\title{
FAKTOR - FAKTOR YANG MEMPENGARUHI PENGAMBILAN KEPUTUSAN PASUTRI DALAM MEMILIH ALAT KONTRASEPSI
}

\section{FACTORS THAT INFLUENCE THE DECISION MAKING COUPLE IN SELECTING CONTRACEPTION}

\author{
Warsini, ${ }^{1}$ Siti Indarti, ${ }^{2}$ Reni Tri Subekti ${ }^{3}$ \\ ${ }^{123}$ Universitas Muhammadiyah Pringsewu \\ Email : Renitri340@gmail.com
}

\begin{abstract}
Factors That Influence The Decision Making Couple In Selecting Contraception. The choice of contraceptive methods in Tanjung Pandan village in 2019/2020 began to shift to the trend of long-term use of contraception, the choice of contraceptive methods for implants, IUDs and sterility has begun to be an option for fertile age couples (PUS) although the choice of using short-term contraceptive methods is also still an option mostly EFA. The purpose of this study is to find out what factors influence the decision-making of couples to choose contraception. This study uses a qualitative descriptive method with cross sectional design. The population in this study is family planning acceptors in the village of TanjungPandan, Bangunrejosubdistrict, Central Lampung regency in 2020. The sample in this study used the Slovin formula of 88 respondents with a purposive sampling technique using a questionnaire sheet.The results of hypothesis testing showed that there was a relationship between age, parity and support of husband and wife to contraception with the average short and long term contraceptive scale of 1,58 with a standard deviation of 0,496 and a standard error of 0,053 , an average age scale $<20$ years, 20 to 30 years and $>30$ years, 1,85 with a standard deviation of 0,766 and a standard error of 0,082 , an average parity scale of 1,73 with a standard deviation of 0,690 and a standard error of 0,074, an average scale of Spousal Support that is 1,56 with a standard deviation of 0,500 and a standard error of 0,053. Pvalue 0,000<0.05 so Ha is accepted and Ho is rejected. Based on the results of the study, couples' decision-making in choosing contraception has a close relationship to reduce the number of parities in couples.

Keywords: Decision Making, Couples, Choosing a Contraception
\end{abstract}

\begin{abstract}
Abstrak: Faktor - Faktor Yang Mempengaruhi Pengambilan Keputusan Pasutri Dalam Memilih Alat Kontrasepsi. Pemilihan metode kontrasepsi di desa Tanjung Pandan pada tahun 2019/2020 mulai bergeser pada tren penggunaan kontrasepsi jangka panjang, pemilihan metode kontrasepsi Implant, IUD dan steril sudah mulai menjadi pilihan PasanganUsia Subur (PUS) meskipun pemilihan penggunaan metode kontrasepsi jangka pendek juga masih menjadi pilihan sebagian besar PUS.Tujuan penelitian ini adalah untuk Mengetahui faktor faktor apa saja yang mempengaruhi pengambilan keputusan pasutri dalam memilih alat kontrasepsi. Penelitian ini menggunakan metode deskriftif kualitatif dengan desain cross sectional. Populasi pada penelitian ini adalah akseptor KB yang ada di desa Tanjung Pandan kecamatan Bangunrejo kabupaten Lampung Tengah tahun 2020. Sampel pada penelitian ini menggunakan rumus Slovin sebanyak 88 responden dengan teknik sampling Purposive Sampling menggunakan lembar kuisioner.Hasil penelitian pengujian hipotesis menunjukkan bahwa terdapat hubungan antara umur, paritas dan dukungan suami istri terhadap kontrasepsi dengan Rata-rata skalakontrasepsi jangkapendekdanpanjangyaitu 1,58 denganstandardeviasi 0,496 danstandar error 0,053, rata-rata skalaumur $<20$ tahun, 20 sampaidengan 30 Tahundan $>30$ Tahunyaitu 1,85 denganstandardevisiasi 0,766 danstandar error 0,082 , rata-rata skalaparitasyaitu 1,73 denganstandardevisiasi 0,690
\end{abstract}


Vol 10 No 1 Januari 2021 | Page 33-41

danstandar error 0,074, rata-rata skalaDukunganSuami/ Istriyaitu 1,56 denganstandardevisiasi 0,500 danstandar error 0,053. Pvalue 0,000<0,05 sehingga Ha diterima dan Ho ditolak. Berdasarkan hasil penelitian tersebut pengambilan keputusan pasutri dalam memilih alat kontrasepsi memiliki hubungan yang erat untuk menekan jumlah paritas pada pasangan pasutri.

Kata Kunci: Pengambilan Keputusan, Pasutri,pemilihan alat Kontrasepsi

\section{PENDAHULUAN}

Pertumbuhan penduduk di dunia mengalami peningkatan dari waktu kewaktu, worldo meter mencatat jumlah penduduk dunia pada tahun 2019 mencapai 7,7 miliar jiwa. Angka tersebut tumbuh 1,08\% dari tahun 2018 yang sebesar 7,6 miliar jiwa. Berdasarkan regional, Asia masih memimpin sebagai wilayah dengan penduduk terbanyak. Tercatat jumlah penduduk asia sebanyak 4,6 miliar jiwa. Sementara negara yang memiliki jumlah penduduk terbanyak adalah tiongkok sebanyak 1,43 miliar. Indonesia merupakan negara ke empat dengan jumlah penduduk terbanyak di dunia. Jumlah penduduk Indonesia dari tahun ke tahun terus meningkat. Menurut data Badan Pusat Statistik (BPS) tahun 2017, tercatat jumlah penduduk di Indonesia tahun 2015 sebanyak 258,2 juta jiwa, tahun 2016 sebanyak 261,1 juta jiwa,tahun 2017 sebanyak 264 juta jiwa dan mencapai jumlah 270,6 juta jiwa pada tahun 2019 .

Setiap negara melakukan berbagai upaya untuk menekan laju pertumbuhan penduduk di negaranya seperti China contohnya, berdasarkan data yang diperoleh dari The United Nations Statistic Division dalam situs resminya di unstat.un.org, hingga tahun 2017 estimasi jumlah penduduk China mencapai $37 \%$ total penduduk Asia. Salah satu kebijakan yang populer sekaligus mengandung kontroversi dalam menekan angka kelahiran merupakan kebijakan satu anak dalam satu keluarga (one- child policy). kebijakan one child policy diperkenalkan sejak tahun 1970'an dan berlangsung selama beberapa dasawarsa, dengan cara mendasar anggaran ini menyatakan bahwa satu keluarga hanya boleh mempunyai satu anak laki- laki atau maksimal dua anak jika anak yang pertama perempuan. Selain itu pemerintah China juga menyerukan supaya ada penundaan pernikahan untuk menjamin terwujudnya program tersebut.

Upaya pemerintah Indonesia dalam menekan laju pertumbuhan penduduk adalah dengan menunjuk suatu badan yang secara spesifik dan khusus bertanggung jawab terhadap pengendalian pertumbuhan penduduk di Indonesia, yaitu Badan Koordinasi Keluarga Berencana Nasional (BKKBN). Keluarga berencana (KB) merupakan suatu program pemerintah yang dirancang untuk menyeimbangkan antara kebutuhan dan jumlah penduduk tersebut dapat dilakukan dengan penggunaan alat-alat kontrasepsi atau penanggulangan kelahiran seperti kontasepsi Pil, Suntik, Implant, IUD, Tubektomi dan sebagainya (Irianto Koes ,2014).

Keluarga berencana telah menjadi salah satu sejarah keberhasilan pada abad-20. Saat ini hampir $60 \%$ pasangan usia subur diseluruh dunia menggunakan kontrasepsi. Hingga saat ini populasi dunia sudah mencapai angka 6 miliar dan lebih dari 120 juta wanita dinegara berkembang memiliki cara untuk mencegah kehamilan (Aurum,2009 ). Menurut data RISKESDAS tahun 2018 proporsi penggunaan alat kontarasepsi setelah persalinan pada perempuan usia 10-54 tahun menurut jenis kontrasepsinya adalah pil sebanyak $0,2 \%$, kondom pria $1,1 \%$, sterilisasi wanita $3,1 \%$, susuk KB (implant ) 4,7\%, suntikan 1 bulan 6,1\%, IUD 6,6 $\%$, pil 8,5 \% dan suntik 3 bulan 42,4\% (Riskesdas, 2018) .

Menurut data dari BPS tahun 2018 presentase wanita berumur 15-49 tahun yang berstatus kawin dan menggunakan KB di provinsi lampung khususnya yaitu pada tahun 2016 sebanyak 67,35\% , tahun 2017 sebanyak $69,70 \%$ dan pada tahun 2018 sebanyak 66, $78 \%$. 
Vol 10 No 1 Januari 2021 | Page 33-41

Sedangkan untuk kecamatan Bangunrejo pencapaian program KB pada tahun 2016 sebanyak 50,6\%, tahun 2017 sebanyak 72, $2 \%$, tahun 2018 sebanyak 32.14\% dan padatahun 2019 sebanyak 84,6\%. ( data puskesmas Bangunrejo, 2019 ). Dan khususnya desa Tanjung Pandan data per januari 2020 diperoleh data dari 392 PUS ada sebanyak 77,5\% pasangan menggunakan kotrasepsi antara lain 67,6\% menggunakan suntik, 9,2\% pil, 16,4\% menggunakan implant, 1,9\% menggunakan IUD, 2,6 \% MOW, dan 2,3\% menggunakan kondom.

Teori Green dan Kruter (2005) mengatakan bahwa penggunaan metode kontrasepsi dapat dipengaruhi oleh umur wanita usia subur, pendidikan, pekerjaan, ketersediaan fasilitas akses perilaku petugas KB dan dukungan. Teori tersebut dibuktikan oleh sebuah penelitian yang dilakukan oleh Seri Ariyati, Sukamdi dan Dyah Widyastuti (2019). Faktor yang mempunyai hubungan pada wanita usia subur dalam memilih metode kontrasepsi adalah umur, pendidikan dan jenis kelamin. Dalam penelitian ini menunjukan presentasi tertinggi pemilihan kontasepsi Non Metode Kontrasepsi Jangka Panjang (MKJP) adalah pada usia 24- 31 tahun.

Pemilihan Kontrasepsi pada Wanita Usia Subur (WUS) salah satunya dipengaruhi oleh paritas. Paritas merupakan jumlah persalinan yang pernah dialami atau banyaknya kelahiran hidup yang dimiliki oleh seorang wanita. Paritas adalah istilah yang menunjukan jumlah kehamilan yang berakhir dengan kelahiran janin yang mampu hidup diluar rahim. Paritas yang terlalu tinggi serta jarak kehamilan yang terlalu dekat akan mempengaruhi ibu dan janin (BKKBN 2016). Wanita dengan paritas multipara dan grande multipara di anjurkan untuk menggunakan metode kontrasepsi jangka panjang karena berada pada fase menjarangkan antara kehamilan 2-4 tahun dan wanita yang merasa sudah cukup dengan jumlah anak yang dimiliki berada dalam fase menghentikan kehamilan (Kemenkes RI, 2015).

Penelitian yang dilakukan oleh Koekoeh Hardjito, Sisca liawaty simanjuntak, Erna rahma yani (2017) yang meneliti hubungan antara paritas dengan pemilihan metode kontrasepsi pada wanita usia subur, didapat kesimpulkan ada hubungan signifikan antara paritas dengan pemilihan metode kontrasepsi pada wanita usia subur. Dalam penelitian ini menunjukan 65 $(39,6 \%)$ WUS dengan paritas primipara didapatkan sebagian besar yaitu 49 0rang atau $(75,4 \%)$ memilih menggunakan kontrasepsi Non MKJP. Sementara dari $100(60,6 \%)$ WUS dengan paritas multipara atau Grandemultipara didapatkan hampir 88 orang atau (88\%) memilih menggunakan MKJP.Selain paritas Dukungan suami untuk menggunakan kontrasepsi merupakan salah satu faktor yang mempengaruhi penggunaan kontasepsi (sharan \& Valente,2002). Hal ini juga dibuktikan oleh penelitian yang dilakukan oleh Zakiah Bakri, Rina Kunde dan Hendro Bidjuni(2019). Penelitian yang dilakukan di wilayah kerja puskesmas Ratona Weru di peroleh kesimpulan ada hubungan antara pengetahuan dan dukungan suami dalam pemilihan kontrasepsi hormonal. Dari penelitian tersebut diperoleh hasil 65,9\% suami mendukung akseptor KB dan 34,1\% suami tidak mendukung akseptor KB.

Berdasarkan survei awal data penelitian yang dilakukan di desa Tanjung Pandan terdapat 392 pasangan usia subur dan 72,7\% menggunakan kontrasepsi dengan berbagai metode yang dipilih oleh pasutri. Dariuraian tersebut maka peneliti bermaksud untuk meneliti " faktor faktor yang mempengaruhi pengambilan keputusan pasutri dalam pemilihan alat kontrasepsi di desa Tanjung pandan. 


\section{Jik

Vol 10 No 1 Januari 2021 | Page 33-41

\section{METODE}

Desain penelitian adalah metode yang digunakan peneliti untuk melakukan penelitian terhadap arah jalannya penelitian. Penelitian ini menggunakan metode deskriftif kualitatif dengan desain cross sectional yaitu penelitian evaluasi yang bertujuan untuk menilai sejauh mana variabel yang diteliti sudah sesuai dengan tolak ukur yang sudah ditentukan, untuk mengetahui faktor- faktor yang mempengaruhi pengambilan keputusan pasutri dalam memilih alat kontrasepsi di desa Tanjung Pandan tahun 2020.

\section{HASIL}

Tabel. 4.9 Variabel Kontrasepsi Terhadap Umur

\begin{tabular}{|c|c|c|c|c|c|}
\hline & & & \multicolumn{2}{|c|}{ Kotrasepsi } & \multirow[b]{2}{*}{ Total } \\
\hline & & & $\begin{array}{l}\text { Jangkapende } \\
\mathrm{k}\end{array}$ & $\begin{array}{l}\text { Jangkapanjan } \\
\mathrm{g}\end{array}$ & \\
\hline \multirow{8}{*}{ Umur } & \multirow{2}{*}{$<20$ Tahun } & Count & 30 & 3 & 33 \\
\hline & & Total & $34,1 \%$ & $3,4 \%$ & $37,5 \%$ \\
\hline & \multirow{2}{*}{ 20-30 Tahun } & Count & 0 & 35 & 35 \\
\hline & & Total & $0,0 \%$ & $39,8 \%$ & $39 \%$ \\
\hline & \multirow{2}{*}{ >30 Tahun } & Count & 7 & 13 & 20 \\
\hline & & Total & $8,0 \%$ & $14,8 \%$ & $22,7 \%$ \\
\hline & \multirow{2}{*}{ Total } & Count & 37 & 51 & 88 \\
\hline & & Total & $42,0 \%$ & $58,0 \%$ & $100 \%$ \\
\hline
\end{tabular}

Berdasarkan tabel diatas hubungan umur terhadap kontrasepsi, responden dengan umur dibawah $<20$ Tahun terdapat 30 responden $34,1 \%$ yang melakukan kontrasepsi jangka pendek, dan 3 responden 3,4\% yang melakukan kontrasepsi jangka panjang, selanjutnya responden dengan umur 20 sampai 30 tahun yang melakukan kontrasepsi jangka pendekt erdapat 0 responden $0,0 \%$ dan jangka panjang 35 Responden $39,8 \%$,sementara dengan umur responden> 30 tahun keatas terdapat 7 responden 8,0\%yang melakukan kontrasepsi jangka pendek dan 13 responden 14,8\% yang melakukan kontrasepsi jangka panjang. Kesimpulan data diatas bahwa responden yang berumur 20 sampai 30 tahun paling banyak melakukan kontrasepsi jangka panjang.

Tabel. 4.10 Chi Squer Test Kontrasepsi terhadap Umur

\begin{tabular}{llll}
\hline & Value & Df & Asymptotic Significance (2-siled) \\
\hline Person Chi-Squer & 58,135 & 2 &, 000 \\
\hline N Valid Case & 88 & & \\
\hline
\end{tabular}

Berdasarkan hasil data chi-squer diatas dimana p-value 58,135 dan Asymptotic Significance (2-Siled) menunjukkan ,000 dimana nilai tersebut di lebih kecil dari>0.05 maka dapat disimpulkan bahwa terdapat hubungan antara kontrasepsi terhadap umur responden. 
Vol 10 No 1 Januari 2021 | Page 33-41

Tabel.4.11 Crosstab Hubungan Kontrasepsit erhadap paritas

\begin{tabular}{|c|c|c|c|c|c|}
\hline & & & \multicolumn{2}{|c|}{ Kotrasepsi } & \multirow{2}{*}{ Total } \\
\hline & & & Jangkapendek & Jangkapanjang & \\
\hline \multirow{8}{*}{ Paritas } & \multirow{2}{*}{1 Anak } & Count & 32 & 4 & 36 \\
\hline & & Total & $15,1 \%$ & $20,9 \%$ & $36,0 \%$ \\
\hline & \multirow{2}{*}{2 Anak } & Count & 0 & 40 & 40 \\
\hline & & Total & $0,0 \%$ & $100,0 \%$ & $100,0 \%$ \\
\hline & \multirow{2}{*}{ Lebihdari 2} & Count & 5 & 7 & 12 \\
\hline & & Total & $41,7 \%$ & $58,3 \%$ & $100,0 \%$ \\
\hline & \multirow{2}{*}{ Total } & Count & 37 & 51 & 88 \\
\hline & & Total & $42,0 \%$ & $58,0 \%$ & $100 \%$ \\
\hline
\end{tabular}

Berdasarkan data diatas hubungan kontrasepsi terhadap paritas, responden dengan paritas berjumlah 1 terdapat 32 responden 15,1\% yang melakukan kontrasepsi jangka pendek, dan 4 responden 20,9 \% yang melakukan kontrasepsi jangka panjang, selanjutnya dengan jumlah responden yang memiliki 2 anak yang melakukan kontrasepsi jangka pendek terdapat 0 responden $0,0 \%$ danjang kapanjang 40 responden $100,0 \%$, sementara dengan responden yang memiliki anak lebih dari 2 terdapat 5 responden $41,7 \%$ dengan memilih kontrasepsi jangka pendek dan 7 responden 58,3\% memilih kontrasepsi jangka panjan. Kesimpulan data diatas bahwa responden yang jumlah anak 2 paling banyak melakukan kontrasepsi jangka panjang.

Tabel. 4.12 Chi Squer Test Kontrasepsi terhadap Paritas

\begin{tabular}{llll}
\hline & Value & Df & Asymptotic Significance (2-siled) \\
\hline Person Chi-Squer & 61,439 & 2 &, 000 \\
N Valid Case & 88 & & \\
\hline
\end{tabular}

Berdasarkan hasil data chi-squerdiatasdimana p-value 61,439 dan Asymptotic Significance (2-Siled) menunjukkan ,000 dimana nilai tersebut di lebih kecil dari>0.05 maka dapat disimpulkan bahwa terdapat hubungan antara kontrasepsi terhadap paritas responden.

Tabel.4.13 Crosstab Hubungan Kontrasepsi terhadap dukungan Suami istri

\begin{tabular}{cccccc}
\hline & & & \multicolumn{2}{c}{ Kotrasepsi } & Total \\
\cline { 1 - 3 } & & & $\begin{array}{l}\text { JangkaPe } \\
\text { ndek }\end{array}$ & $\begin{array}{c}\text { JangkaPa } \\
\text { njang }\end{array}$ & \\
$\begin{array}{c}\text { Dukungan } \\
\text { pasangan }\end{array}$ & Terlibat & Count & 27 & 12 & 39 \\
& \multirow{2}{*}{ TidakTerlibat } & Total & $30,7 \%$ & $13,6 \%$ & $100,0 \%$ \\
& & Count & 10 & 39 & 49 \\
& \multirow{2}{*}{ Total } & Total & $11,4 \%$ & $76,5 \%$ & $100,0 \%$ \\
& & Count & 37 & 51 & 88 \\
& & Total & $42,0 \%$ & $58,0 \%$ & $100 \%$ \\
\hline
\end{tabular}

Berdasarkan data dukungan suami istri diatas terhadap kontrasepsi, responden dengan dukungan terlibat jangka panjang sebanyak 27 responden 30,7\% dan dukungan jangka pendek sebanyak 12 responden atau 13,6\%. Selanjutnya dukungan suami istri dengan tidak ikut terlibat 
dalam kontrasepsi jangka panjang sebanyak 10 responden 11,4\%, dukungan kontrasepsi tidak terlibat jangka pendek 39 responden $76,5 \%$. Kesimpulan data diatas bahwa responden yang tidak terlibat dalam memberikan dukungan kontrasepsi jangka panjang paling banyak dibandingkan responden yang memberikan dukungan jangka pendek.

Tabel. 4.14 Chi Squer Test Kontrasepsi terhadap Dukungan

\begin{tabular}{llll}
\hline & Value & df & Asymptotic Significance (2-siled) \\
\hline Person Chi-Squer & 21,243 & 1 &, 000 \\
N Valid Case & 88 & & \\
\hline
\end{tabular}

Berdasarkan hasil data chi-squer diatas dimana p-value 21,243 dan Asymptotic Significance (2-Siled) menunjukkan ,000 dimana nilai tersebut di lebih kecil dari>0.05 maka dapat disimpulkan bahwa terdapat hubungan antara kontraseps iterhadap dukungan suami.

\section{PEMBAHASAN}

Kontrasepsi yaitu pencegahan terbuahinya sel telur oleh sperma (konsepsi) atau pencegahan menempelnya sel telur yang telah dibuah ikedidnding rahim ( Nugrohodan Utama,2014). Berdasarkan distribusi frekuensi, jumlah responden yang memilih kontrasepsi jangka panjang lebih banyak dari pada responden yang memilih kontrasepsi jangka pendek, dengan jangka panjang sebanyak 51 responden 58,0\% danjangka pendek sebanyak 37 responden $42,0 \%$ dengan rata-rata 1,58 .

Hubungan antara kontrasepsi dengan umur dilihat dari umur responden dimana responden dengan umur <20 Tahun berjumlah 33 Responden 37,5\%, umur 20 sampaidengan 30 tahun berjumlah 35 responden $39,8 \%$ dan $>30$ tahun berjumlah 20 responden 22,7 dengan rata-rata 1,85 dan chi-squer ,000dimanapadataraftersebutlebihkecildari>0.05 makadapat disimpulkan bahwa Ha memiliki hubungan antara kontrasepsi terhadap umur. Hal ini sejalan dengan sebuah penelitian yang dilakukan oleh Seri Ariyati, Sukamdi dan Dyah Widyastuti (2019) bahwa faktor yang mempunyai hubungan pada wanita usia subur dalam memilih metode kontrasepsi adalah umur, pendidikan dan jenis kelamin. Dalam penelitian yang dilakukan oleh Seri ariyati dkk menunjukan presentasi tertinggi pemilihan kontasepsi Non Metode Kontrasepsi Jangka Panjang (MKJP) adalah pada usia 24- 31 tahun, sedangkan dalam penelitian yang penulis lakukan menunjujkan bahwa presentasi tertinggi pemilihan alat kontrasepsi pada usia 20- 30 tahun. Masih tingginya angka PUS yang berusia dibawah 20 tahun didesa Tanjung pandan harus mendapat perhatian lebuh dari berbagai pihak karena itu dapat meningkatkan resiko tinggi ganngguan kesehatan reproduksi wanita.

Hubungan antara kontrasepsi dengan paritas dilihat dari responden yang memiliki jumlah anak 1 terdapat 36 responden 40,9\%, responden yang memiliki 2 anak 40 responden $45,5 \%$ dan responden yang miliki anak lebih dari 212 responden $13,6 \%$ dengan rata-rata 1,85 dan chisquer ,000 dimana pada taraf tersebut lebih kecil dari>0.05 makadapat disimpulkan bahwa Ha memiliki hubungan antara kontra sepsi terhadap Paritas. Hal ini juga dibuktikan oleh penelitian yang dilakukan oleh Koekoeh Hardjito, Sisca liawaty simanjuntak, Erna rahma yani (2017) yang meneliti hubungan antara paritas dengan pemilihan metode kontrasepsi pada wanita usia subur didapat kesimpulan ada hubungan signifikan antara paritas dengan pemilihan metode 
Vol 10 No 1 Januari 2021 | Page 33-41

kontrasepsi pada wanita usia subur. Dalam penelitian yang penulis lakukan PUS yang memiliki anak 2 paling banyak melakukan kontrasepsi.

Hubungan antara kontrasepsi dengan dukungan suami/ istri dimana dukungan suami/ istri yang terlibat lebih rendah dibandingkan dengan dukungan suami istri yang tidak terlibat dengan responden yang terlibat sebesar 39 responden $44,3 \%$ dan responden yang tidak terlibat 49 responden $55,7 \%$ dengan rata-rata 1,56 dan chi-squer, 000 dimana pada taraf tersebut lebih kecil dari $>0.05$ maka dapat disimpulkan bahwa Ha memiliki hubungan antara kontrasepsi terhadap dukungan suami/ istri. Hal ini juga dibuktikan oleh penelitian yang dilakukan oleh Zakiah Bakri, Rina Kunde dan Hendro Bidjuni(2019). Penelitian yang dilakukan di wilayah kerja puskesmas Ratona Weru di peroleh kesimpulan ada hubungan antara pengetahuan dan dukungan suami dalam pemilihan kontrasepsi hormonal. Dari penelitian tersebut diperoleh hasil $65,9 \%$ suami mendukung akseptor KB dan 34,1\% suami tidak mendukung akseptor KB.

Penelitian yang dilakukan di Desa Tanjung pandan menunjukan bahwa pasangan yang mendukung dalam memilih alat kontrasepsi lebih sedikit dibandingkan yangn tidak mendukung pasangan nya, hal ini dikarenakan kurangnnya pengetahuan dari pasangan terhadap berbagai jenis metode kontrasepsi dan juga kurangnya keperdulian dari pasangan khususnnya suami dalam memilih alat kontrasepsi, yang salah satunya ditunjukan dari tidak terlibatnya suami dalam memilih alat kontrasepsi, sehingga ketika dikemudian hari ditemukan keluhan atau efek samping yang dialami oleh istri yang diakibatkan oleh penggunaan kontrasepsi suami cenderung menyalahkan istri.

\section{SIMPULAN}

Dari hasil pengujian hipotesis dan pembahasan dalam penelitian ini sesuai tujuan seperti yang telah disebutkan dalam pendahuluan dapat diambil beberapa kesimpulan antara lain sebagai berikut: Padapenelitianinididapatkanresponden yang mengunakan kontrasepsi jangka panjang lebih banyak yaitu sebanyak 51 orang (58\%) responden terbanyak berumur 20-30 tahun yaitu 35 orang $(39,8 \%)$,responden dengan jumlahanak 2 terdapat 40 responden $(45,5 \%)$ dan responden denganpasangan tidak mendukung terlibat 49 responden $(55,7 \%)$. Dari ketiga variabel yang diteliti dalam penelitian ini yaitu umur, paritas dan dukungan pasangan terhadap metode kontrasepsi yang dipilih oleh PUS menunjukan bahwa pasangan yang tidak terlibat atau tidak mendukung memilih kontrasepsi jangka panjang adalah yang paling besar yaitu $58 \%$. Terdapat hubungan kontrasepsi terhadap umur, paritas dan dukung suami istri di desa Tanjung pandan dalam memilih alat kontrasepsi dengan nilai $p$-valueadalah 0,000

\section{SARAN}

Adapun saran dari penelitian ini adalah sebagai berikut :Bagi penyuluh lapangan desa tanjung pandan diharapkan dapat melakukan sosialisasi-sosialisasi terkait pemilihan alat kontrasepsi bagi pasangan suami istri di desa Tanjung pandan. Bagi bidan desa atau tenaga kesehatan yang melakukan pelayanan kontrasepsi di desa Tanjung pandan agar melibatkan kedua pasangan dalam memilih alat kontrasepsi. Bagi masyarakat desa Tanjung pandan diharapakan untuk meningkatkan pemahaman dalam mengenal pemilihan alat kontrasepsi dan saling memberikan dukungan antara suami istri. Bagi peneliti selanjutnya, melakukan penelitian 


\section{Jik

Vol 10 No 1 Januari 2021 | Page 33-41

dengan memperhatikan faktor-faktor selain yang digunakan dalam penelitian ini seperti faktor sosial, budaya, agama dan faktor-faktor lainnya.

\section{DAFTAR PUSTAKA}

Ariyati, seri, Sukamdi, Dyah Widyastuti.(2019). Faktor- faktor yang mempengaruhi pemilihan metode kontrasepsi (kasus di kecamatan Sebrang Ulu I Kota Palembang). Majalah Geografi Indonesia

Aryanti, h.(2014). Faktor- faktor yang berhubungan dengan pennggunaan kontrasepsi pada wanita kawin usia dini di kecamatan Aikmel Kabupaten Lombok Timur Denpasar. Universitas Udayana

Aurum , setya. D.N.(2009). Panduan lengkap pelayanan Kb terkini. Yogyakarta: Mitra cendekia

Bakri, zakiyah, risa Kundre, Hendro bidjuni.(2019). Faktor faktor yang berhubungan dengan pemilihan metode kontrasepsi pada wanita usia subur di wilayah kerja puskesmas rotana weru. Universitas Samratulangi: e jurnal keperawatan

Bernandus, Johana D, Agnes medianung, Gresty Masi. (2013). Faktor - faktor yang berhubungan dengan pemilihan alat kontrasepsi dalam rahim (AKDR) bagi akseptor $k b$ di puskesmas Jailolo. Journal e- Ners volume 1. Universitas Samratulangi Manado

BKKBN .( 2015). BKKBN rencana strategis badan kependudukan dan keluarga berencana nasional tahun 2015-2019. DKI

BKKBN.(2015) . Buku saku materi bantu penyuluhan kependudukan dan keluarga berencana dan pembangunan keluarga. Medan: BKKBN

Depkes RI. 2014.Pedoman Manajemen PelayananKeluargaBerencana.DirjenBina Gizi dan $K I A$ : Jakarta Kemenkes

Dinas kesehatan Provinsi Lampung.(2016). Rencana Strategis Dinas Kesehatan Provinsi Lampung Tahun 2015- 2019.

Handayani, D. (2010). Faktor - faktor yang mempengaruhi ibu dalam pengambilan keputusan memilih alat kontrasepsi dalam rahim diwilayah bidan praktek swasta titik tri suparti Boyolali. Jurnal KesMaDaSka

Hardjito , Koekoeh, Sisca Liawaty Simanjuntak, Erna Rahmayani. (2017). Pemilihan metode kontrasepsi berdasarkan status paritas wanita usia subur (wus)

https//idm.wikipedia.org/wik/Pengambilan_keputusan

Irianto, Koes.(2014). Pelayanan keluarga berencana. Bandung : Alfa beta

KEMENKES RI.(2018). Hasil utama riskesdas 2018. Jakarta : KEMENKES RI

Lontaan, Anita, kusmiyati, Robin Dompas.(2014). Faktor- faktor yang berhubungan dengan pemilihan metode kontrasepsi pasanga usia subur di puskesmas damau kabupaten talaud. Manado: JIDAN 


\section{Jik

Vol 10 No 1 Januari 2021 | Page 33-41

Notoatmojo, Soekidjo.(2010). Dasar- dasar metodologi penelitian klinis. Edisi .3. Jakarta: PT. Rineka Cipta

Notoatmojo, Soekidjo.(2010). Kesehatan masyarakat ilmu dan seni .Jakarta: PT Asdi Mahasatya

Notoatmojo, Soekidjo.(2012). Metodologi penelitian kesehatan.Jakarta: PT. Rineka Cipta

Pinem, S. (2009\}. Kesehatan reproduksi dan kontrasepsi . Jakarta: Trans info medika

Proverawati, A .(2010) .Panduan memilih kontrasepsi, yogyakarta . Nuha Medika

Septalia , Rendys, Nunik Puspitasari.(2016). Faktor yang mempengaruhi pemilihan metode kontrasepsi. Jurnal Biometrika Dan Kependudukan.

Setiasih, Sri. Bagus Widjonarko, Tinuk Istiarti. (2016). Analisis faktor- faktor yang mempengaruhi pemilihan metode kontrasepsi jangka panjang (mjkp) pada wanita pasangan usia subur (pus) di kabupaten kendal tahun 2013. Jurnal Promosi Kesehatan Indonesia

Susanto, dkk., (2015). Hubungan Antara Dukungan Suami Terhadap Istri Dengan Keputusan Pengunaan Alat Kontrasepsi Di Wilayah Kerja Puskesmas Ngemplak Boyolali. Jurnal Kesehatan Komunitas

Syukaisih. (2015). Faktor- faktor yang berhubungan dengan pemilihan metode kontrasepsi di puskesmas rambah samo kabupaten rokan hulu.Jurnal kesehatan komunitas.

Utama, Juvinda Eka Priya, Ratna Sari H, Erti iktiarini D. (2016). Hubungan peran suami terhadap pemilihan jenis alat kontasepsi $k b$ pada ibu di kelurahan kebonsari kabupaten jember. Jurnal Ilmiah Kesehatan Media Husada vol. 5 